\title{
Sera from diabetic pregnant women contain reduced titres of inhibiting factors on killer cell activity
}

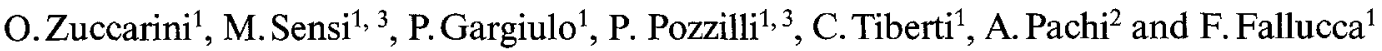 \\ ${ }^{1}$ I Cattedra di Medicina Costituzionale ed Endocrinologia and ${ }^{2}$ Istituto di Puericultura Perinatale, University of Rome 'La Sapienza', Italy; \\ ${ }^{3}$ Department of Diabetes and Immunogenetics, St Bartholomew's Hospital, London, UK
}

\begin{abstract}
Summary. The presence of Fc-receptor-blocking factors in the sera of normal and insulin-dependent diabetic pregnant women was investigated by means of an antibody-dependent cellmediated cytotoxicity assay. Sera from normal pregnant women induced a significant depression of antibody dependent cell-mediated cytotoxicity when compared with sera from normal and diabetic non-pregnant women $(p<0.0001$; $p<0.002$, respectively). The effect of sera from diabetic pregnant women, however, was not different from that observed with sera from normal and diabetic non-pregnant women.
\end{abstract}

Thus, we confirm the presence of Fc-receptor-blocking factors in the sera of normal pregnant women. The higher cytotoxicity levels measured in the presence of sera from pregnant women with insulin-dependent diabetes suggests that the titres of such factors are reduced in this condition.

Key words: Pregnancy, diabetes mellitus, serum-blocking factors, antibody-dependent cell-mediated cytotoxicity, killer cells.
The presence of blocking factors in sera from normal pregnant women is well documented [1]. Thus, sera from these women have been shown to impair lymphocyte transformation induced by phytohaemagglutinin [2], to inhibit mixed lymphocyte reaction [3], and nonspecific cytotoxic cell activity [4]. The presence of these factors is probably of great importance since they appear to have a protective role in the survival of the fetus and their absence has been linked to the occurrence of repeated spontaneous abortions $[5,6]$.

Recently, non-cytotoxic fragment crystallizable (Fc)-receptor-blocking antibodies to paternal B lymphocytes have been described in sera of normal pregnant women [7]. Again, these antibodies were not found in women undergoing spontaneous abortion [7]. A condition associated with increased risk of fetal morbidity, including spontaneous abortion, is diabetes mellitus. Several reports have suggested clearly that, although intermediary metabolism plays a major role in the aetiology of complications of diabetic pregnancy [8], abnormalities of the immune function may also be operative.

The aim of this study was to investigate the presence of non-specific 'protective' Fc-receptor-blocking factors in sera from diabetic pregnant women and to correlate these data with the outcome of pregnancy, the metabolic control of the mother, the presence of immune complexes and the perinatal complications of diabetic pregnancy.

\section{Subjects and methods}

\section{Subjects}

Sera were collected from the following subjects: eight normal pregnant women (mean age 26 years; range 22-30 years), 14 insulin-dependent diabetic pregnant women (mean age 29 years, range $17-40$ years; mean $\pm S D$ duration of disease $9 \pm 4$ years); eight normal nonpregnant fertile women (mean age 32 years, range 21-40 years); seven insulin-dependent diabetic non-pregnant fertile women (mean age 24 years, range $20-28$ years; mean \pm SD duration of disease $7 \pm$ 4 years). Sera were collected during the last trimester of pregnancy.

\section{Maternal and neonatal characteristics}

The following parameters were investigated:

1. Maternal metabolic control: this included monthly evaluation of glycosylated haemoglobin, 3 monthly blood glucose and daily glycosuria measurements and the occurrence of hypoglycaemia and/or acetonuria. According to the results, the metabolic control was classified as 'good' if glycosylated haemoglobin was $<7.5 \%$, blood glucose did not exceed $7.7 \mathrm{mmol} / 1$, glycosuria was rare and hypoglycaemia and acetonuria did not occur. The metabolic control was considered 'poor' when glycosylated haemoglobin was $>7.5 \%$, blood glucose was $>7.7 \mathrm{mmol} / \mathrm{l}$, glycosuria was frequent and hypoglycaemia and/or acetonuria occurred occasionally [9].

2. Immune complexes were measured in maternal sera by the $\mathrm{Cla}$ method [10]. Quantitation of the circulating immune complexes was obtained by reference of sample duplicates to the uptake of serially diluted heat-aggregated immunoglobulin G. Results are expressed in $\mu \mathrm{g}$ aggregate equivalents $/ \mathrm{ml}$ undiluted serum. 


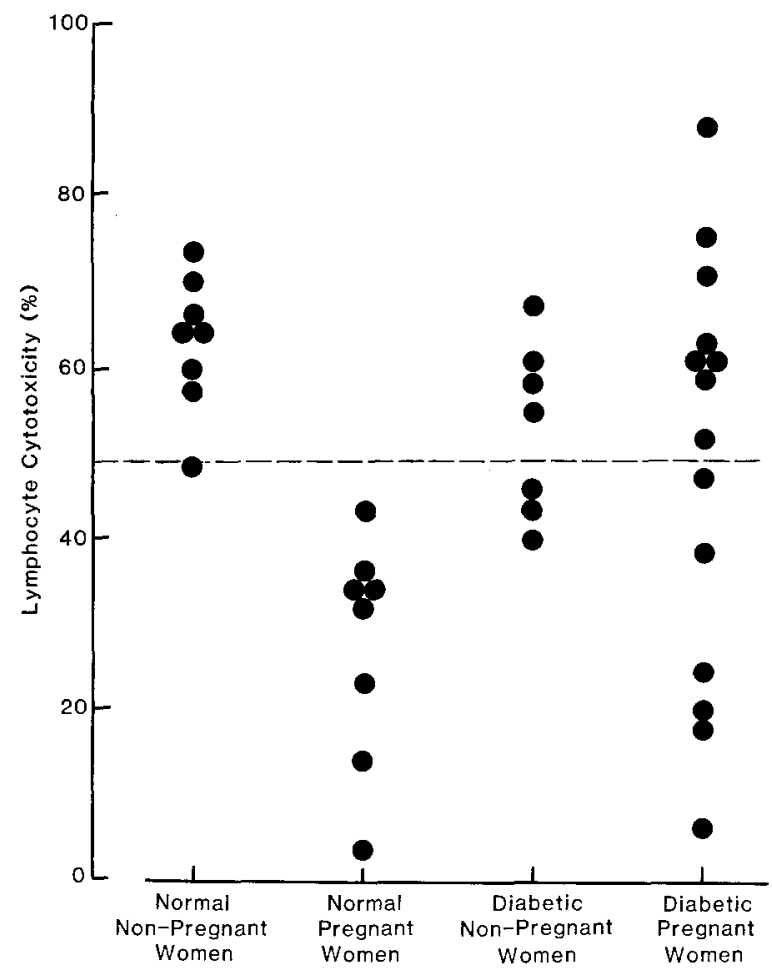

Fig. 1. Single cytotoxicity values observed in the presence of each type of serum. The broken horizontal line indicates the limit of $2 \mathrm{SD}$ above the mean cytotoxicity level measured in the presence of sera from normal pregnant women

3. Neonatal complications: the presence of macrosomia ( $>90^{\circ}$ percentile Lubcenko charts), hypoglycaemia $(<1.4 \mathrm{mmol} / 1)$, hypocalcaemia $(<1.7 \mathrm{mmol} / \mathrm{l})$, hyperbilirubinaemia $(>171 \mathrm{mmol} / \mathrm{l})$ and respiratory distress syndrome were investigated in all newborn infants.

\section{Preparation of effector cells}

Mononuclear cells were obtained throughout the experiments from the same normal donor. This subject had no family history of diabetes or autoimmune disease. The cells were obtained by gradient centrifugation of defibrinated venous blood over Ficoll Hypaque [11], washed and suspended at a concentration of $2.5 \times 10^{6} \mathrm{cell} / \mathrm{ml}$ in TC $199 \mathrm{cul}-$ ture medium supplemented with Hepes buffer $(20 \mathrm{mmol} / \mathrm{l})$, antibiotics (streptomycin sulphate, $0.1 \mathrm{mg} / \mathrm{ml}$ and benzylpenicillin $100 \mathrm{U} / \mathrm{ml}$ ) and $10 \%$ heat inactivated fetal calf serum.

\section{Preparation of target cells}

Chang liver cells (Flow Laboratories, Irvine, UK) were used as target cells. Approximately $1.0-3.0 \times 10^{6}$ cells were labelled with ${ }^{51} \mathrm{Cr}$ by incubation for $60 \mathrm{~min}$ at $37^{\circ} \mathrm{C}$ with $100 \mu \mathrm{Ci}$ sodium $\left({ }^{51} \mathrm{Cr}\right.$ )-chromate (Amersham International, Amersham, Bucks, UK). The cells were washed three times and adjusted to a concentration of $5 \times 10^{5} \mathrm{cel} 1 / \mathrm{ml}$ in culture medium. Half of the cell suspension was mixed with an equal volume of heat-inactivated fetal calf serum containing heat-inactivated rabbit anti-Chang antiserum at a dilution of 1:2500 (sensitized cells). To the remaining cell suspension, an equal volume of fetal calf serum containing heat-inactivated normal rabbit serum at the same dilution of 1:2500 was added (non-sensitized cells).

\section{Serum mediated effect on antibody-dependent cell mediated cytotoxicity}

${ }^{51} \mathrm{Cr}$-labelled sensitized or non-sensitized Chang liver cell suspension $\left(2.5 \times 10^{4}\right.$ cells, $\left.100 \mu \mathrm{l}\right)$ and $100 \mu \mathrm{l}\left(2.5 \times 10^{5} \mathrm{cells}\right)$ of mononuclear cell suspension were dispensed in triplicate in microplate wells; $50 \mu \mathrm{l}$ of each heat inactivated human serum were then added to the wells. After $18 \mathrm{~h}$ of incubation at $37{ }^{\circ} \mathrm{C}$ in $5 \% \mathrm{CO}_{2}$ humidified atmosphere, the supernatant was collected by means of the Titertek collection system (Flow Laboratories) and the radioactivity measured. In each experiment the mean of triplicate values was considered to calculate the percentage cytotoxicity according to the formula:

$\%$ lymphocyte cytotoxicity $=$

cpm (effector cells + sensitised target cells - spontaneous release) $\times 100$ $\mathrm{cpm}$ (maximum release - spontaneous release)

\section{Statistical analysis}

The results are given as mean \pm SD and were analysed by means of the Mann-Whitney U test and analysis of variance.

\section{Results}

Mean lymphocyte cytotoxicity in the presence of sera from normal non-pregnant women was not statistically different from that measured with sera from diabetic non-pregnant women $(68 \pm 8 \%$ versus $53 \pm 10 \%$; MannWhitney $U$ test). However, in the presence of sera from normal pregnant women, cytotoxicity $(23 \pm 13 \%)$ was significantly reduced compared with that measured in sera from normal $(p<0.0001)$ and diabetic $(p<0.002)$ non-pregnant women. In contrast, lymphocyte cytotoxicity in the presence of sera from diabetic pregnant women $(48 \pm 23 \%)$ was not statistically different from that observed from normal and diabetic women and significantly greater than that measured in normal pregnant women $(p<0.05)$. The single cytotoxicity values measured in the presence of each serum are shown in Figure 1. Sera from eight diabetic patients showed a total lack of inhibitory activity on killer cells, each of the cytotoxicity values being above $2 \mathrm{SD}$ of the mean value for normal pregnant women. When normal and diabetic pregnant women were compared, the cytotoxicity levels were not found to reflect differences in age and parity (analysis of variance). Similarly, in diabetic pregnancy, no correlation was found between cytotoxicity values and outcome of pregnancy, metabolic control of the mother, presence of immune complexes or perinatal complications (Table 1). All pregnancies were brought to term without complications.

\section{Discussion}

The finding that antibody-dependent cell-mediated cytotoxicity is impaired in the presence of sera from normal pregnant women supports the concept of the existence of Fc-receptor-blocking factors. The absence of such factors in over $50 \%$ of the sera from diabetic pregnant women suggests that some physiological immune mechanisms of control are lacking in these women. In other studies, the absence of such 'protective' factors has been correlated with the occurrence of spontaneous 
Table 1. Clinical and experimental details of the diabetic pregnant women studied

\begin{tabular}{rllllll}
\hline Subjects & $\begin{array}{l}\text { Age } \\
\text { (years) }\end{array}$ & $\begin{array}{l}\text { Number of } \\
\text { pregnancies }\end{array}$ & $\begin{array}{l}\text { Metabolic } \\
\text { control }\end{array}$ & $\begin{array}{l}\text { Immune } \\
\text { complexes }\end{array}$ & $\begin{array}{l}\text { Lymphocyte } \\
\text { cytotoxicity } \\
(\%)\end{array}$ & $\begin{array}{l}\text { Neonatal } \\
\text { complications }\end{array}$ \\
\hline 1 & $17(28)^{\mathrm{a}}$ & $0(2)^{\mathrm{a}}$ & Poor & $++^{\mathrm{b}}$ & $61(23)^{\mathrm{a}}$ & Jaundice \\
2 & $23(30)$ & $0(1)$ & Poor & +++ & $38(14)$ & Macrosomia, jaundice, hypoglycaemia \\
3 & $29(23)$ & $4(0)$ & Good & - & $52(35)$ & Macrosomia, jaundice \\
4 & $25(27)$ & $0(1)$ & Good & - & $60(34)$ & Macrosomia, respiratory distress syndrome \\
5 & $33(24)$ & $0(0)$ & Good & + & $91(43)$ & Macrosomia, jaundice, hypoglycaemia \\
6 & $40(22)$ & $2(0)$ & Good & + & $70(4)$ & Hypoglycaemia, respiratory distress syndrome \\
7 & $27(29)$ & $0(2)$ & Good & + & $61(35)$ & \\
8 & $38(25)$ & $0(0)$ & Good & - & $48(34)$ & Macrosomia \\
9 & 30 & 1 & Good & - & 75 & Jaundice \\
10 & 39 & 1 & Poor & - & 59 & Macrosomia, jaundice, hypoglycaemia \\
11 & 21 & 0 & Good & + & 25 & Macrosomia, jaundice, hypoglycaemia \\
12 & 19 & 0 & Poor & - & 4 & Jaundice, respiratory distress syndrome \\
13 & 29 & 0 & Good & - & 19 & Jaundice \\
14 & 34 & 2 & Good & - & 19 & \\
\hline
\end{tabular}

a Values in parentheses indicate corresponding data for normal pregnant women;

$\mathrm{b}+++,++,+,-$ represent $>60 ;>30<60 ;>6<30$; and $<6 \mu$ g equivalents of heart-aggregated immunoglobulin $\mathrm{g} / \mathrm{ml}$ undiluted serum

abortions [5, 7]. However, since no abortion occurred in any of our diabetic women, the finding of a successful pregnancy associated with lack of a specific killer cell inhibiting serum factor is of interest, but needs further investigation. On the basis of our preliminary results, we can speculate that the absence of Fc-receptor-blocking factors alone is not incompatible with a successful pregnancy in diabetic women and the concurrent absence of more than one 'protective' serum factor with different immunosuppressive action might be necessary to precipitate fetal rejection.

Previous studies have pointed to the possible role played by various serum factors of maternal, fetal and maternal-fetal interface origins in the modulation of the immune response $[12,13]$. Thus hormones, such as progesterone [14] and human chorionic gonadotrophin [15], or other substances such as prostaglandins of decidual origins [16], transferrin [17], uteroglobulin [18], alphafetoproteins [19] and some as yet undefined immunosuppressive molecules produced by the trophoblast [20], could be involved in immune regulation either acting as immunosuppressor molecules or making class I MHC antigens inaccessible for interaction with $\mathrm{T}$ cells.

In normal pregnant women it has been shown that placental antigens and Fc-receptor-bearing cells tend to bind maternal antibodies and immune complexes, thus blocking their transfer into the fetal circulation [12]. A possible explanation for the absence of Fc-receptorblocking factors in sera from some diabetic pregnant women could be a pathologically higher rate of antibody absorption by the trophoblast.

In conclusion, evidence has been presented that late human diabetic pregnancy is associated with reduced titres of Fc-receptor-blocking factors. However, this finding is not related to the outcome of pregnancy, metabolic control, presence of immune complexes, age and parity of the mother and perinatal complications.
As the possible correlation with these parameters could be masked by the small number of cases studied, a full prospective study is needed to investigate the time of appearance and the course, not only of the Fc-receptor-blocking factors, but also of other 'protective' serum factors during diabetic pregnancy in order to clarify their role in the pathogenesis of spontaneous abortion and maternal fetal complications.

Acknowledgements. This work was supported by grants from the Cenci-Bolognetti Foundation, Rome (O.Zuccarini) and from the Joint Research Board, St Bartholomew's Hospital, London (M.Sensi).

\section{References}

1. Editorial (1983) Maternal blocking antibodies, the fetal allograft and recurrent abortion. Lancet 2: 1175-1176

2. Griffin JFT, Beck I (1983) A longitudinal study of leucocyte numbers and mitogenesis during the last ten weeks of human pregnancy. J Reprod Immunol 5: 239-247

3. Bissenden JG, Ling NR, Mackintosh R (1980) Suppression of mixed lymphocyte reactions by pregnancy serum. Clin Exp Immunol 39: 195--202

4. Barratt DS, Rayfield LS, Brent L (1982) Suppression of natural cell-mediated cytotoxicity in man by maternal and neonatal serum. Clin Exp Immunol 47: 742-748

5. Rocklin RE, Kitzmiller JL, Carpenter CB, Garovoy MR, David JR (1976) Maternal-fetal relation: absence of an immunological blocking factor from the serum of women with chronic abortions. N Engl J Med 295: 1209-1213

6. Stimson WH, Strachan AF, Shepherd A (1979) Studies on the maternal immune response to placental antigens: absence of a blocking factor from the blood of abortion-prone women. $\mathrm{Br} \mathrm{J}$ Obstet Gynaecol 86: 41-45

7. Power DA, Cotto GRD, Mason RJ, MacLeod AM, Stewart GM, Stewart KN, Shewan WG (1983) The fetus as an allograft: evidence for protective antibodies to HLA-linked paternal antigens. Lancet 2: 701-704

8. Gabbe SG (1979) Application of scientific rationale to the management of the pregnant diabetic. In: Merkatz IR, Adam PAJ 
(eds) The diabetic pregnancy. A perinatal perspective. Grune \& Stratton, New York, pp 45-56

9. Fallucca F, Gargiulo P, Troili F, Fiore R, Zuccarini O, Gerlini G, Pachì A, Iavicoli M (1983) Influence of maternal metabolic control and insulin antibodies on neonatal complications in infants of diabetic mothers. Diabetologia 25: 153 (Abstract)

10. Lambert PH, Dixon FJ, Zubler RH, Agnello V, Cambiaso C, Casali P, Clarke J, Cowdery JS, McDuffie FC, Hay FC, MacLennan ICM, Masson P, Muller-Eberhard HJ, Peuttinen K, Smith M, Tappeiner G, Theophylopoulos AN, Verrust P (1978) A collaborative study for the evaluation of 18 methods for detecting immune complexes. J Clin Lab Immunol 1: 1-15

11. Boyum A (1968) Isolation of leucocytes from human blood. Scand J Clin Lab Invest 21 (Suppl 97): 37-50

12. Faulk WP (1980) The maternofoetal relationship. In: Dausset J, Faugerot M (eds) Immunology 1980. IV Congress of Immunology Paris, Academic Press, New York, pp 1094-1116

13. Lala PK, Chatterjee-Hasroumi S, Kearns M, Montgomery B, Colavincenzo V (1983) Immunobiology of the feto-maternal interface. In: Moller G (ed) Immunological review, Munksgaard, Copenhagen, Denmark, pp 87-116

14. Clemens LE, Siiteri PK, Stites DP (1979) Mechanism of immunosuppression of progesterone on maternal lymphocyte activation during pregnancy. J Immunol 122: 1978-1981

15. Han T (1974) Inhibitory effect of human chorionic gonadotrophin on lymphocyte blastogenic response to mitogen antigen and allogeneic cells. Clin Exp Immunol 18: 529-533
16. Williams KI, Downing I (1977) Prostaglandin and thromboxane production by rat-decidual microsome. Prostaglandins 14: 813816

17. Faulk WP, Johnson PM (1977) Immunological studies of human placentae. Identification and distribution of proteins in mature chorionic villi. Clin Exp Immunol 27:365-368

18. Mukerjee AB, Ulane RE, Agarwal AK (1982) Role of uteroglobulin and transaminase in masking the antigenicity of implanting rabbit embryos. Am J Reprod Immunol 2: 135-139

19. Murgita RA (1976) The immunosuppressive role of alpha-fetoprotein during pregnancy. Scand J Immunol 5: 1003-1007

20. Pavia CS, Stites DP, Fraser R (1981) Transplantation-antigen expression on murine trophoblast detection by induction of specific allo-immunity. Cell Immunol 64: 162-165

Received: 4 May 1984

and in revised form: 17 October 1984

Dr. O.Zuccarini

$\mathrm{II}^{\circ}$ Clinica Medica (Endocrinologia I)

Policlinico Umberto $1^{\circ}$

I-00161 Rome

Italy 